\title{
CD4 cell counts in adults with newly diagnosed HIV infection in Barbados
}

\author{
Krishna R. Kilaru, ${ }^{1}$ Alok Kumar, ${ }^{2}$ and Namrata Sippy ${ }^{1}$
}

Suggested citation

Kilaru KR, Kumar A, Sippy N. CD4 cell counts in adults with newly diagnosed HIV infection in Barbados. Rev Panam Salud Publica. 2004;16(5):302-7.

ABSTRACT Objective. To evaluate the absolute CD4 cell counts of all the newly diagnosed HIVinfected persons who presented at the Ladymeade Reference Unit (LRU), which serves as the national HIV/AIDS referral and treatment center for the country of Barbados.

Design and Methods. The study group was comprised of HIV-infected adults who had been diagnosed with HIV infection and referred to the LRU between January and December 2002. All the patients referred to the LRU had a CD4 cell count done at their first visit to the unit, as part of the routine workup to assess their disease status and need for antiretroviral therapy.

Results. Of the 106 newly diagnosed adults, 62 of them (58.5\%) were males, who had a median age at presentation of 40 years; the other 44 of them (41.5\%) were females, and their median age at presentation was 36 years. Nearly one-fifth (18.2\%) of the females were aged 16 25 years, whereas only $8.1 \%$ of the males were in this age group. The majority (57.6\%) of the study group were diagnosed because they presented with an HIV/AIDS-related illness. Overall, the median CD4 cell count at the time of diagnosis was $183 / \mu L ; 52$ of 103 adults $(50.5 \%)$ with a newly diagnosed HIV infection had a CD4 cell count that was $<200$. Among males, the median CD4 cell count was 161/ $\mu \mathrm{L}$, and 32 (53.3\%) of 60 males had CD4 cell counts $<200$. In contrast, among females, the median CD4 cell count was 223, and 20 (46.5\%) of 43 females had a CD4 cell count that was $<200 / \mu L$. However, this difference in the proportion of males and females with a CD4 cell count less than $200 / \mu \mathrm{L}$ was not statistically significant $(\mathrm{P}=0.63)$. Conclusions. At the time of HIV diagnosis, over one-half of the adults had an initial CD4 cell count that was consistent with relatively advanced disease. Proportionally more women than men presented at a younger age, and proportionally more women than men presented in the early stages of the disease. These patterns indicate a clear need for enhanced educational efforts regarding the importance of HIV testing for at-risk individuals across Barbados. This testing could improve efforts to reduce transmission as well as the prognosis for patients who receive antiretroviral therapy.

Key words HIV infections, CD4 lymphocyte count, risk factors, Barbados.

Depletion of CD4+ $\mathrm{T}$ cells is one of the hallmarks of progression of HIV

1 Ladymeade Reference Unit, St. Michael, Barbados.

2 Queen Elizabeth Hospital, St. Michael, Barbados. Send correspondence to: Alok Kumar, The Queen Elizabeth Hospital, School of Clinical Medicine \& Research, University of West Indies (Cave Hill Campus), St. Michael, Barbados; fax: (246) 4295374; e-mail: bhavna@sunbeach.net infection (1). The absolute CD4 cell count is used routinely in the evaluation and monitoring of HIV-infected persons (2). This is a standard test to stage the disease and to make therapeutic decisions regarding antiretroviral treatment and prophylaxis for opportunistic pathogens. It is also a relatively reliable indicator of prognosis, and it complements the viral load assay. These two assays independently predict clinical progression and survival (3). CD4 cell counts have been found to have good correlation with development of various complications in HIV/AIDS (4). Even though the 
English-speaking Caribbean has the second highest prevalence of HIV infection in the world, there are no reported studies from that area on the CD4 cell count in HIV-infected persons at presentation (5).

Barbados implemented its expanded National HIV / AIDS Program in early 2002, including with provision of free antiretroviral treatment. Since then, HIV-infected persons have been referred for treatment and follow-up at the national HIV/AIDS referral and treatment center, which is located at the Ladymeade Reference Unit (LRU), in the city of Bridgetown.

In our research we studied the initial absolute CD4 cell counts for all the newly diagnosed HIV-infected persons who presented at the LRU. This information would help to determine at what stage in the disease the HIVinfected persons present for treatment and other interventions. This study would also provide baseline data on CD4 cell counts in HIV-infected adults at presentation for comparison with future studies, which could be used as a tool to evaluate the impact of interventions aimed at early detection of HIV infection in the community. The findings from this study might also be useful in predicting the impact of highly active antiretroviral therapy (HAART) at the community level, given the current conditions in Barbados. Finally, this study would be useful for providing parameters to inform surveillance activities, resource requirements planning, and management strategies.

\section{DESIGN AND METHODS}

The LRU serves as the sentinel center for HIV/AIDS surveillance and management for all of Barbados. It is a specialist HIV/AIDS center, with a wide range of services, including voluntary counseling and testing, treatment (including free antiretroviral medications and referral services), monitoring of treatment response with CD4 cell counts and viral load analysis, follow-up, and supportive care of HIV-infected persons. Many of the persons referred to the LRU have been diagnosed with HIV/AIDS at the Queen Elizabeth Hospital, which is the central referral hospital for the country.

Two other sources of referral are public polyclinics, which serve as the provider of primary health care in the country, and the private offices of general practitioners. Persons may be tested on various occasions at the polyclinics or those private offices for medical illnesses suspected to be due to HIV infection. These occasions can include during antenatal screening, if they present with sexually transmitted diseases, during voluntary counseling and testing (VCT) of otherwise healthy adults who have requested an HIV test, or when they are tested for such other reasons as for insurance purposes or immigration purposes. Persons may also present to the LRU either for VCT or when a sex partner is diagnosed as being HIV-infected.

The study group was comprised of HIV-infected adults who had been diagnosed with HIV infection and referred to the LRU between January and December 2002 for care and treatment of their HIV infection. HIVinfected children (age less than 16 years) were excluded from the study.

For all the patients referred to the LRU with a diagnosis of HIV infection, the information recorded for them included age, gender, date of diagnosis of their HIV infection, and the referring center. The reason for the HIV test was also noted from the referral letter. A complete clinical examination was performed to assess their clinical status, and a blood specimen was collected for CD4 analysis.

\section{CD4 analysis}

The blood sample was drawn into a 2-mL tube containing EDTA anticoagulant and processed within 6 hours of sample venesection. The samples were prepared and run on the COULTER EPICS XL flow cytometer (Beckman Coulter Inc., Fullerton, California, United States of America), according to the manufacturer's instructions. The following reagents (also obtained from Beckman Coulter) were used for the CD4 cell counts: (1) FlowCheck, (2) Flow-Set and Flow-Count fluorospheres, (3) IMMUNO-TROL cells, (4) OptiLyse C lysing solution, (5) COULTER CLONE phosphatebuffered saline (PBS), (6) CYTO-STAT tetraCHROME, and (7) CD45-FITC, CD4-RD1, CD8-ECD and CD3-PC5 monoclonal antibodies (MAbs). We added $100 \mu \mathrm{L}$ of whole blood to $10 \mu \mathrm{L}$ of $\mathrm{MAb}$ and then allowed the mixture to incubate for 10 minutes at room temperature. Cells were lysed using $500 \mu \mathrm{L}$ of OptiLyse C solution for another 10 minutes, following the addition of $500 \mu \mathrm{L}$ of PBS solution. The samples were stored at $4{ }^{\circ} \mathrm{C}$ and analyzed the following day. Flow-Count fluorospheres were added immediately prior to analysis for absolute count determination.

The samples were analyzed with the tetraONE software for four-color analysis installed on the flow cytometer. Quality control was performed to align the lasers of the flow cytometer and to automatically adjust the voltages across the photomultiplier tubes of the flow cytometer, using FlowCheck and Flow-Set fluorospheres, respectively. IMMUNO-TROL control cells were run to ensure precision and accuracy. Prepared samples were then run, with the absolute CD4 counts reported as cells per $\mu \mathrm{L}$.

All information was recorded in the patient's case file and subsequently transferred into a computer database, which was used to generate tables and graphs. Epi Info 6 software (Centers for Disease Control and Prevention, Atlanta, Georgia, United States) was used for the statistical analysis, including the chi-square test. Our analysis included estimation of $95 \%$ confidence intervals (95\% CIs) for proportions and associated two-tail probabilities for the difference between two independent proportions (6).

\section{RESULTS}

In Barbados during the study period 181 persons tested positive for HIV infection for the first time. These people 
FIGURE 1. Age distribution of the newly diagnosed HIV-infected adults, Barbados, 2002

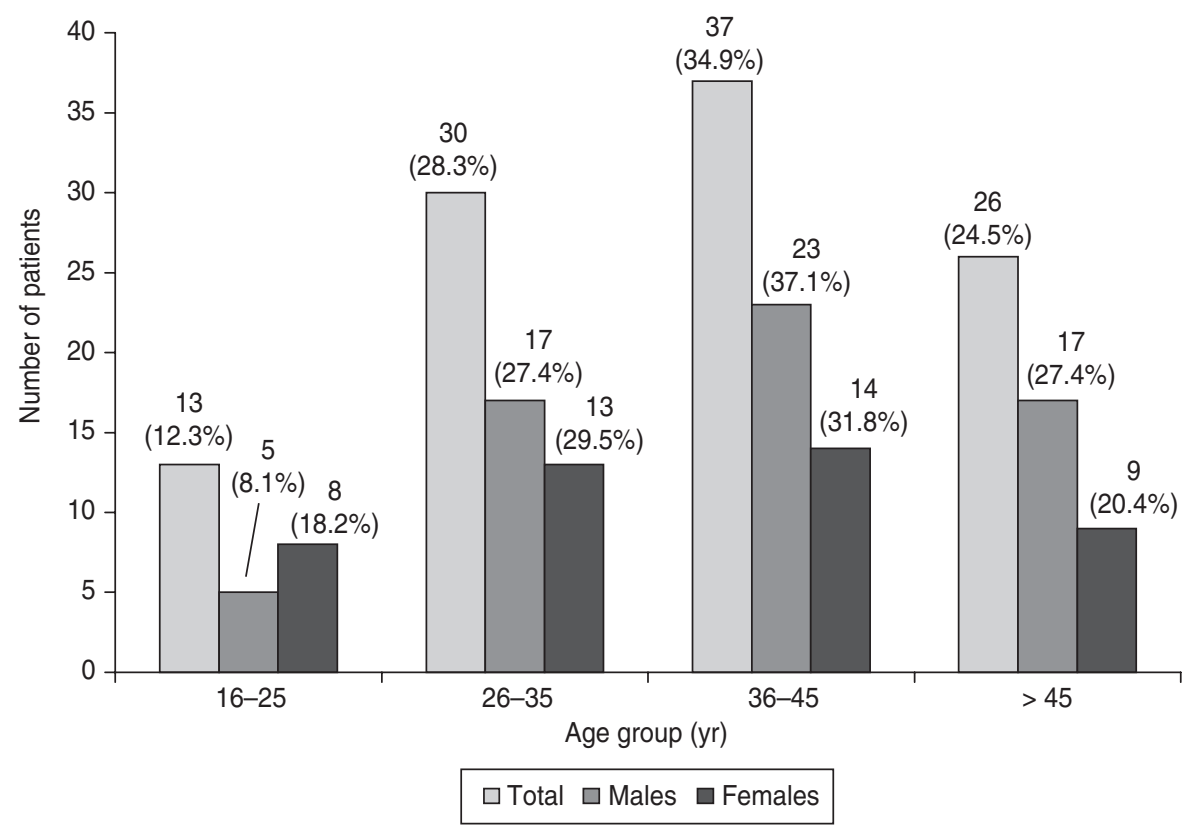

were tested for HIV at polyclinics, the private offices of general practitioners, or at the Queen Elizabeth Hospital. Of these 181 newly diagnosed HIVinfected persons, 106 of them $(58.6 \%)$ presented at the LRU. Of the 106, 62 of them $(58.5 \%)$ were males, with the median age at presentation being 40 years (range, 19-62 years); the remaining 44 persons $(41.5 \%)$ were females, with a median age at presentation of 36 years (range, 16-66 years).

Figure 1 shows the age distribution of the adults with newly diagnosed HIV infection. Overall, $12.3 \%$ of the newly diagnosed HIV-infected adults (95\% confidence interval $(\mathrm{CI})=6.9 \%$ to $24.4 \%$ ) were in the age group of $16-25$ years. A higher proportion of females $(18.2 \%, 95 \% \mathrm{CI}=8.7 \%$ to $33.2 \%)$ than of males $(8.1 \%, 95 \% \mathrm{CI}=3.0 \%$ to $18.5 \%$ ) were in the age group of 16 to 25 years. However, this male-female difference was not statistically significant (chi-square test, $P=0.205$ ).

The reasons for the HIV testing in these newly diagnosed persons are shown in Table 1. The most common reason was presenting with symptomatic conditions that could be attributed to HIV infection. This was fol- for females the median CD4 cell count was $223 / \mu \mathrm{L}$ (range $=1$ to 1714 ).

Overall, $38(36.9 \%)$ of the 103 newly diagnosed HIV-infected adults were asymptomatic and were categorized as "Class A," using the 1993 AIDS surveillance case definition for adolescents and adults of the United States Centers for Disease Control and Prevention (CDC) (Table 2). Of the 103 persons with a newly diagnosed HIV infection, 30 of them (29.1\%) had AIDS-defining conditions ("Class $\mathrm{C}^{\prime}$ ) at the time of their presentation. Of the 52 people who presented with CD4 counts less than $200 / \mu \mathrm{L}, 4$ of them $(7.7 \%)(95 \%$ $\mathrm{CI}=3.0 \%$ to $18.2 \%$ ) were asymptomatic at the time of their presentation.

Table 3 shows the clinical presentation in relation to the CD4 counts at the time of diagnosis of HIV infection. Out of the 32 newly diagnosed HIVinfected adults with a CD4 cell count greater than $350 / \mu \mathrm{L}, 28$ of them $(87.5 \%)$ were either asymptomatic or were symptomatic with nonspecific generalized lymphadenopathy only. In contrast, out of the 52 newly diagnosed HIV-infected adults with a CD4 cell count less than $200 / \mu \mathrm{L}$, only 9 of them $(17.3 \%)$ were asymptomatic or had nonspecific generalized lymphadenopathy alone. CD4 cell count was 183 . Of 103 patients, 52 of them $(50.5 \%)(95 \%$ $\mathrm{CI}=40.5 \%$ to $60.4 \%$ ) had a CD4 cell count that was $<200 / \mu \mathrm{L}$. Among the male patients, $53.3 \%$ of them $(95 \% \mathrm{CI}=$ $40.1 \%$ to $66.1 \%$ ) had a CD4 cell count that was $<200 / \mu \mathrm{L}$, compared to $46.5 \%$ of the female patients $(95 \% \mathrm{CI}=31.5 \%$ to $62.2 \%$ ) (chi-square $P=0.63$ ). Among males the median CD4 cell count was $161 / \mu \mathrm{L}$ (range $=0$ to 1027 ), whereas

\section{DISCUSSION}

In general, $\mathrm{HIV}$-infected persons with lower CD4 counts have been infected for longer periods of time as compared to those with higher CD4 counts (7). In addition, recent studies have reported that individuals with

TABLE 1. Reasons for HIV testing of newly diagnosed HIV-infected adults, with number, percent, and 95\% confidence interval (95\% Cl), Barbados, 2002

\begin{tabular}{lrrr}
\hline \multicolumn{1}{c}{ Reason for testing } & No. & $\%$ & $95 \% \mathrm{Cl}$ \\
\hline Symptomatic conditions attributed to HIV infection & 32 & 30.2 & $21.8-40.0$ \\
AIDS-defining illness & 29 & 27.4 & $19.4-37.0$ \\
Voluntary counseling and testing of healthy adults & 12 & 11.3 & $6.2-19.3$ \\
Positive consort & 10 & 9.4 & $4.9-17.1$ \\
Antenatal voluntary counseling and testing & 7 & 6.6 & $2.9-13.6$ \\
Sexually transmitted infection & 3 & 2.8 & $0.7-8.6$ \\
Other & 13 & 12.3 & $6.9-20.4$ \\
\hline
\end{tabular}


FIGURE 2. CD4 cell counts at diagnosis, Barbados, 2002

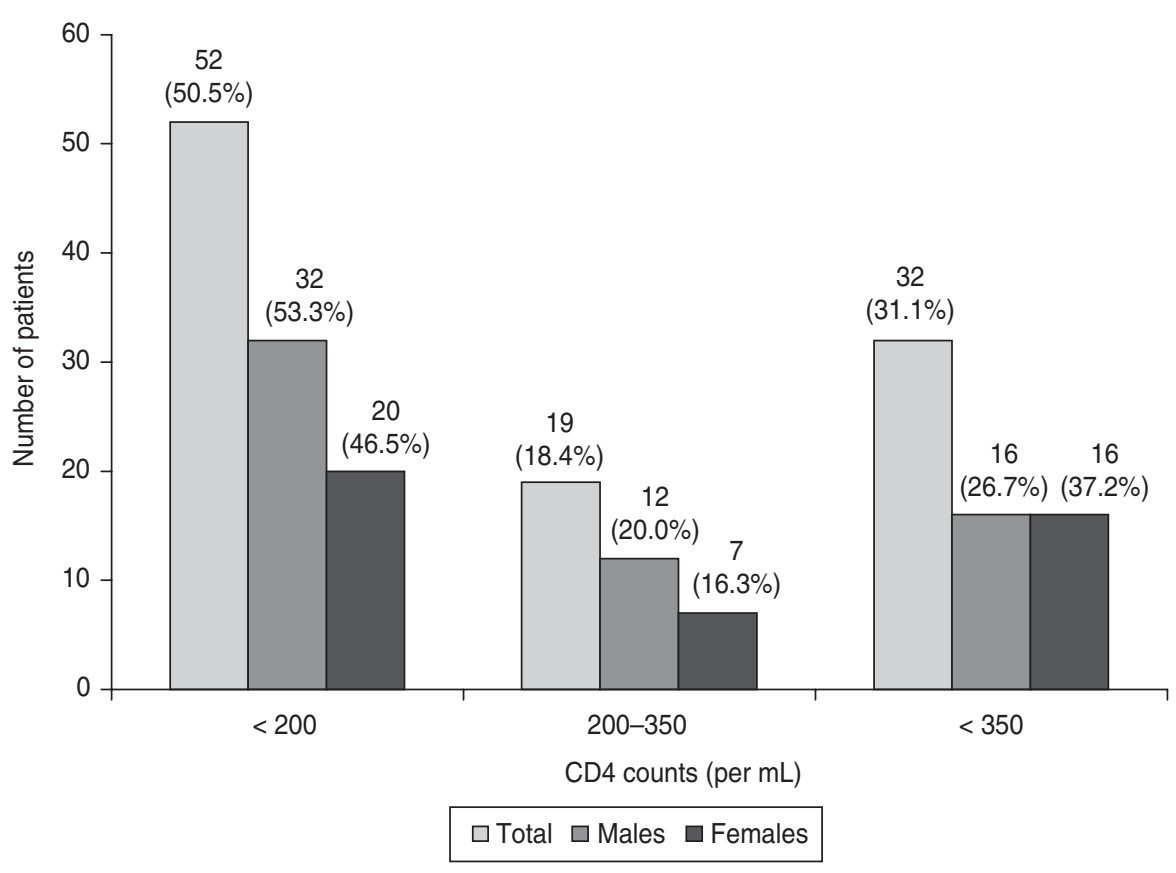

CD4 cell counts $<200 / \mu \mathrm{L}$ have both a poorer response to HAART therapy and a worse prognosis than do individuals with higher CD4 counts at the time of initiation of therapy (8-10). Our data from Barbados show that $68.9 \%$ of the newly diagnosed HIVinfected adults had relatively advanced HIV disease, as reflected by their CD4 cell counts $\leq 350 / \mu \mathrm{L}$ (Figure 2). Of particular concern is the fact that $50.5 \%$ of this study group had a CD4 cell count $<200 / \mu \mathrm{L}$ at the time of diagnosis. These percentages are higher than those reported in some studies $(11,12)$ but similar to the percentages from a study in Mexico (13).

TABLE 2. Clinical and immunological classifications of the newly diagnosed HIV-infected adults, Barbados, 2002

\begin{tabular}{|c|c|c|c|c|c|c|c|c|}
\hline \multirow[b]{3}{*}{ Immunological class } & \multicolumn{6}{|c|}{ No. in clinical class } & & \\
\hline & \multirow{2}{*}{\multicolumn{2}{|c|}{$\begin{array}{c}\text { A } \\
\text { (asymptomatic) }\end{array}$}} & \multirow{2}{*}{\multicolumn{2}{|c|}{$\begin{array}{c}\text { B } \\
\text { (symptomatic } \\
\text { (not AIDS)) }\end{array}$}} & \multirow{2}{*}{\multicolumn{2}{|c|}{$\begin{array}{c}C \\
\text { (AIDS-defining } \\
\text { illness) }\end{array}$}} & \multicolumn{2}{|c|}{ Total } \\
\hline & & & & & & & No. & $\%$ \\
\hline 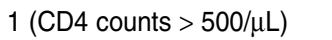 & 13 & & 5 & & 0 & & 18 & 17.5 \\
\hline 2 (CD4 counts $200-500 / \mu \mathrm{L})$ & 21 & & 9 & & 3 & & 33 & 32.0 \\
\hline $3(\mathrm{CD} 4$ counts $<200 / \mu \mathrm{L})$ & 4 & & 21 & & 27 & & 52 & 50.5 \\
\hline Total (no.; \%) & 38 & $36.9 \%$ & 35 & $34.0 \%$ & 30 & $29.1 \%$ & 103 & 100.0 \\
\hline
\end{tabular}

newly diagnosed HIV infected adults were included in clinical category B (non-AIDS-defining illness attributed to the HIV infection) or clinical category C (AIDS-defining condition) at the time of their presentation to the LRU (14). In addition, over one-tenth (4 of 38) of those who were in category A (asymptomatic) had a CD4 cell count $<200 / \mu \mathrm{L}$. This represented nearly a tenth (4 of 52) of the adults who had CD4 cell counts $<200 / \mu \mathrm{L}$ (Table 2). Among the cases with CD4 cell counts between $200 / \mu \mathrm{L}$ and 500/ $\mu \mathrm{L}$, fewer than a tenth (3 of 33) had an AIDS-defining condition, and 21 of 33 $(63.4 \%)$ were asymptomatic at the time of diagnosis. For cases with CD4 cell counts $>500 / \mu \mathrm{L}$, none had an AIDSdefining condition, and over twothirds of these cases (13 of 18) were asymptomatic. Compared to results recently reported by Sackoff and Shin from New York City (15), our study found a higher proportion of adults who were in category A (asymptomatic) or category B (non-AIDSdefining illness attributable to HIV infection) with similar immune suppression. This may also have been a reason for late presentation. This may suggest that in the Barbados population that clinical manifestations lag behind the CD4 cell count depletion. However, further studies would be needed to assess this possibility.

Based on current knowledge from available studies, it is obvious that these HIV-infected adults in Barbados who present late in the course of the disease, with a CD4 cell count $<200$ / $\mu \mathrm{L}$, are at risk for rapid disease progression and worse prognosis despite initiation of HAART therapy $(10,16)$. It is also clear from our findings that provision of HAART therapy free of cost may not on its own guarantee the anticipated levels of change in the health-seeking or VCT-seeking behavior of the general public and the people at risk for HIV infection.

In the Barbados study population, $12.3 \%$ of HIV-infected adults were in the age group of 16-25 years (Figure 1). A higher proportion of females (18.2\%) presented by 25 years of age than was true for males $(8.1 \%)$. This is in contrast 
TABLE 3. Correlation of CD4 cell count (cells/ $\mu \mathrm{L}$ ) and presenting illness, Barbados, 2002

\begin{tabular}{lccc}
\hline Presenting illness & $\begin{array}{c}\text { Count }<200 \\
(52 \text { adults })\end{array}$ & $\begin{array}{c}\text { Count }=200-350 \\
(19 \text { adults })\end{array}$ & $\begin{array}{c}\text { Count }>350 \\
(32 \text { adults })\end{array}$ \\
\hline Oropharyngeal candidiasis & 17 & 3 & 0 \\
Significant weight loss & 13 & 3 & 2 \\
Pneumocystis carinii pneumonia & 11 & 2 & 0 \\
Toxoplasmosis & 10 & 0 & 0 \\
Asymptomatic & 4 & 7 & 16 \\
Generalized lymphadenopathy & 5 & 2 & 12 \\
Esophageal candidiasis & 3 & 0 & 0 \\
Cryptococcal meningitis & 1 & 1 & 0 \\
Wasting syndrome & 1 & 0 & 4 \\
Other & 16 & 1 & \\
\hline
\end{tabular}

with findings reported from Mexico (13). We found that a higher proportion of males had a CD4 cell count $<200 / \mu$ L than did females (Figure 2). Similar observations have been made in other studies $(11,17)$. Thus it is clear that females tend to present earlier in the course of HIV illness than do males. In Barbados we found that routine VCT offered during pregnancy may have contributed to women being detected at an earlier stage. Seven out of the 44 females with newly diagnosed HIV infection were diagnosed by antenatal voluntary counseling and testing (Table 1). Moreover, 8 of the 12 persons in the category of "voluntary counseling and testing of healthy adults" were females who had tested negative during earlier antenatal voluntary counseling and testing.

In conclusion, our study demonstrates that over one-half of the adults in this study group in Barbados had an initial CD4 cell count at the time of diagnosis that was consistent with relatively advanced disease. As compared to males a larger proportion of females presented at a younger age, and females presented at an earlier stage of the disease process. The fact that a large proportion of persons learn of HIV infection relatively late in the course of the disease emphasizes the need for enhanced educational efforts regarding the importance of HIV testing for at-risk individuals across Barbados. This in turn could improve both efforts to reduce transmission and the prognosis for patients who receive antiretroviral therapy. Despite these efforts, stigma and discrimination are likely to remain major obstacles to accessing health services, and these barriers will need to be addressed in a more effective way.

Acknowledgements. We thank S. Adomakoh at the Chronic Disease Research Centre; Dr. Timothy C. Roach, Clinical Director, LRU; Dr. A. Abayomi, Director of Laboratories at LRU; and Dr. N. Adomakoh, Ministry of Health, Barbados. We also thank Dr. A. Best, Miss A. Gumbs, and Miss D. Murphy at the LRU for their assistance with the data collection. We also wish to thank all the subjects of this study, whose cooperation made this study possible.

\section{REFERENCES}

1. Shearer WT, Rosenblatt HM, Schluchter MD, Mofenson LM, Denny TN. Immunologic targets of HIV infection: T cells. Ann NY Acad Sci. 1993;693:35-51.

2. United States of America, Centers for Disease Control and Prevention. Guidelines for prophylaxis against Pneumocystis carinii pneumonia for persons infected with human immunodeficiency virus. MMWR. 1989;38:S5-S6.

3. Mellors JW, Munoz A, Giorgi JV, Margolick JB, Tassoni CJ, Gupta P, et al. Plasma viral load and CD4 lymphocytes as prognostic markers of HIV-1 infection. Ann Intern Med. 1997;126:946-54

4. Hanson DL, Chu SY, Farizo KM, Ward JW. Distribution of CD4+ T-lymphocytes at diagnosis of acquired immunodeficiency syndromedefining and other human immunodeficiency virus-related illnesses. The Adult and Adolescent Spectrum of HIV Disease Project Group. Arch Intern Med. 1995;155:1537-42.

5. Joint United Nations Programme on HIV/ AIDS. Report on the global HIV/AIDS epidemic, June 2001. Available from: http:// www.unaids.org/publications/index.html [Internet site]. Accessed 11 January 2002.

6. Newcombe RG. Two-sided confidence intervals for the single proportion: comparison of seven methods. Stat Med. 1998:17;857-72.

7. Stein DS, Korvick JA, Vermund SH. CD4+ lymphocyte cell enumeration for prediction of clinical course of human immunodeficiency virus disease: a review. J Infect Dis. 1992; 165(2):352-63.

8. Sterling TR, Chaisson RE, Keruly J, Moore $\mathrm{RD}$. Improved outcomes with earlier initiation of highly active antiretroviral therapy among human immunodeficiency virusinfected patients who achieve durable virologic suppression: longer follow-up of an observational cohort study. J Infect Dis. 2003; 188(11):1659-65.

9. Garcia F, De Lazzari E, Plana M, Castro P, Mestre G, Nomdedeu M, et al. Long-term CD4+ T-cell response to highly active antiretroviral therapy according to baseline CD4+ T-cell count. J Acquir Immune Defic Syndr. 2004;36(2):702-13
10. Hogg RS, Yip B, Chan KJ, Wood E, Craib KJ, O'Shaughnessy MV, et al. Rates of disease progression by baseline CD4 cell count and viral load after initiating triple-drug therapy. JAMA. 2001;286(20):2568-77.

11. Gupta SB, Gilbert RL, Brady AR, Livingstone SJ, Evans BG. CD4 cell counts in adults with newly diagnosed HIV infection: results of surveillance in England and Wales, 1990-1998. CD4 Surveillance Scheme Advisory Group. AIDS. 2000;14(7):853-61.

12. Dybul M, Bolan R, Condoluci D, Cox-Iyamu R, Redfield R, Hallahan CW, et al. Evaluation of initial CD4+ T cell counts in individuals with newly diagnosed human immunodeficiency virus infection, by sex and race, in urban settings. J Infect Dis. 2002;185(12): 1818-21.

13. Guarner J, Uribe-Zuniga P, HernandezTepichin G, Terantoledo X, Del Rio C. Comparison of CD4+ T-cell counts in men and women recently diagnosed with HIV infection in Mexico City, Mexico. AIDS. 1997;11(5): 701-2. 
14. From the Centers for Disease Control and Prevention. 1993 revised classification system for HIV infection and expanded surveillance case definition for AIDS among adolescents and adults. JAMA. 1993;269:729-30.

15. Sackoff JE, Shin SS. Trends in immunologic and clinical status of newly diagnosed HIV-positive patients initiating care in the HAART era. J Acquir Immune Defic Syndr. 2001;28(3): 270-2.
16. Phillips AN, Staszewski S, Weber R, Kirk O, Francioli P, Miller V, et al. HIV viral load response to antiretroviral therapy according to the baseline CD4 cell count and viral load. JAMA. 2001;286(20):2560-7.

17. Samet JH, Freedberg KA, Savetsky JB, Sullivan $\mathrm{LM}$, Stein MD. Understanding delay to medical care for HIV infection: the long-term non-presenter. AIDS. 2001;15(1):77-85.
Manuscript received 18 December 2003. Accepted for publication 18 August 2004.

RESUMEN Objetivo. Evaluar los recuentos de células CD4 de toda persona con un diagnóstico reciente de infección por VIH que acudió a la Unidad de Remisión Ladymeade (URL), que es el centro nacional de Barbados para la remisión y el tratamiento de casos de inRecuentos de células CD4
en adultos con diagnóstico
reciente de infección por VIH
en Barbados fección por VIH y sida.

Métodos. El grupo de estudio se compuso de adultos con infección por VIH en quienes el diagnóstico y la remisión a la URL se habían hecho entre enero y diciembre de 2002. A todos los pacientes remitidos a la URL se les había efectuado un recuento de células CD4 en su primera consulta a la unidad como parte de la serie habitual de pruebas realizadas para determinar en qué estado se encontraba la enfermedad y si había necesidad de administrar antirretrovíricos.

Resultados. De los 106 adultos con un diagnóstico reciente, 62 (58,5\%) eran varones y tenían una edad mediana de 40 años cuando enfermaron; los otros 44 (41,5\%) eran mujeres y tenían una edad mediana de 36 años al enfermar. Casi una quinta parte $(18,2 \%)$ de las mujeres se encontraban entre los 16 y 25 años de edad, mientras que solamente $8,1 \%$ de los varones pertenecían a ese grupo etario. A la mayoría $(57,6 \%)$ de las personas en el grupo de estudio se les hizo el diagnóstico cuando consultaron por trastornos asociados con la infección por VIH o el sida. En general, el recuento mediano de células CD4 cuando se hizo el diagnóstico fue de $183 / \mu \mathrm{L} ; 52$ de 103 adultos $(50,5 \%)$ con un diagnóstico reciente de infección por VIH tenían un recuento de células CD4 <200/ $\mu \mathrm{L}$. En los varones, el recuento mediano de células CD4 fue de $161 / \mu \mathrm{L}$, y 32 de 60 varones $(53,3 \%)$ tenían recuentos de células CD4 $<200 / \mu \mathrm{L}$. En cambio, el recuento mediano de células CD4 en las mujeres fue de $223 / \mu \mathrm{L}$, y 20 de 43 mujeres $(46,5 \%)$ tenían un recuento $<200 / \mu \mathrm{L}$. No obstante, esta diferencia en la proporción de varones y mujeres con recuentos de células CD $4<200 / \mu \mathrm{L}$ no fue estadísticamente significativa $(P=0,63)$.

Conclusiones. En el momento del diagnóstico de infección por VIH, más de la mitad de los adultos tuvieron un recuento inicial de células CD4 compatible con la enfermedad en etapa relativamente avanzada. Fue mayor el porcentaje de mujeres que de hombres en quienes el diagnóstico se hizo a edad temprana, y también fue mayor el porcentaje de mujeres que de hombres en quienes la enfermedad se diagnosticó en etapa incipiente. Estas tendencias apuntan a la necesidad de fortalecer en todo Barbados las actividades educativas en torno a la importancia del tamizaje de personas en riesgo. Este tipo de tamizaje podría mejorar los esfuerzos dirigidos a reducir la transmisión, así como el pronóstico de los pacientes en tratamiento con antirretrovíricos. 